\title{
Enthusiasms and Two Diderot Questions
}

1967 HAS NEVER BECOME an emblematic year but its affective and intellectual climate sure felt incubational. Something major seemed on the horizon, we impatiently anticipated it becoming a "Revolution," and my generation then needed quite some time to admit that "May 1968 in Paris" had not really been one. Of course I joined the SDS (the German Socialist Students' Association) on the morning of the very same mid-October day (I don't remember the exact date) on the afternoon of which I enrolled for my first semester at the University of Munich. "German Literature" and "Romance Literatures" (in that order) were the two subject matters, curricula, departments that I chose, with much less conviction and enthusiasm for "literature" than I pretended. My father, with the ultimate mindset of a true surgeon, had convinced me that there was no place in medicine for the psychiatry I was dreaming of as a profession and, on the other hand, doing Romance literatures (which in those German years meant French literature with appendixes in Italian and Spanish) gave me the vague illusion of continuing to live in Paris, where I had spent part of my final year of secondary education at Lycée Henri IV, without any notion of the grand tradition that this name carried. What I knew and felt about my studies at the very beginning was quite vague, especially compared to the form that the SDS had me sign in order to confirm that, quite literally, I believed in 
Marxism as "the only Scientific and True Worldview." And things turned really disappointing for me that fall. In all those many courses on "leftist" topics, I can say today, enthusiasm and inspiration stayed on the horizon, never to become present, whereas those classes that pretended to be politically neutral (almost a dying genre then) only recycled the same worn-out concepts of praise without contours that I was sufficiently familiar with from my Gymnasium. The one surprising exception was an introductory seminar on “Diderot's Aesthetic Writings," taught by Dr. Ursula Schick, that I took along with three or four other students and that I had probably chosen because, on my way to school every day in Paris, I had regularly walked by the Diderot statue on Boulevard Saint-Germain and liked the smile on the greenishshimmering metal face of the eighteenth-century author. In January 1968, I gave an in-class presentation on "Eloge de Richardson," Diderot's heavily enthusiastic praise for the contemporary English novelist, and although its tone struck me as "typically bourgeois," as I critically stated, Denis Diderot had begun to grow on me. I could not have said why it happened, but Diderot must have been the one reason why, after my first semester, I ended up not changing from literature to law, as I had thought I should for all practical and spiritual purposes - and even made "Romance Literatures" my primary area of studies, instead of "German Literature." Ever since then, through fifty intellectual and altogether happy professional years, as I have progressively and self-deprecatingly left behind the ideals of the SDS, Diderot and his prose have been with me, in a sympathy that is both profound and peripheral, both unconditional and arbitrary. When about a decade ago, all of a sudden and in a tone that sounded like an order, my friend Karl Heinz Bohrer said that he expected at least one more serious academic (wissenschaftliches) book from me, instead of so much essay writing, I immediately knew that it had to be about Diderot, more precisely about the unknown reasons for that profound and yet peripheral sympathy. This was the first Diderot question I ever had. Soon it became clear that I shared an uncertainty about the grounds of my enthusiasm with the greatest (and also with some not so great) Diderot scholars. For Diderot's prose awakens sympathy in many readers-and yet seems to escape all attempts at a comprehensive description. Several times the problem had me on the verge of giving up on a book that I did not need and that nobody (except Bohrer) particularly wanted me to write. At one 
such moment of hesitancy, the famous pianist Alfred Brendel, during a joint fellowship in Berlin, remarked in passing and in public that I reminded him of Diderot. This was too much, of course, but I also-and not only silentlyregistered that Brendel had made explicit what I had not even dared to dream over so many years. My subsequent embarrassment and pride turned into the impulse for a second Diderot question, the question of whether my own more-than-fifty-year-old sense of affinity with him had not just become one intense case of his much wider-and growing-attraction for intellectuals in the twenty-first century. 
This page intentionally left blank 
PROSE OF THE W O R L D 
This page intentionally left blank 